AJH

ISSN : 0973-4767
Article history :

Received : 20.08 .2020

Accepted : 23.11 .2020

\section{Pharmacognosy and medicinal value of some exotic fruits and vegetables consumed in India}

\author{
Garsh Pant, Vijaya Lobo ${ }^{1}$, Anagha Santhosh ${ }^{1}$ and Shashank Verma ${ }^{1}$
}

Author for correspondence :

Harsh Pant

Department of Botany, St. Xavier's College (Autonomous), Mumbai (M.S.) India

Email : harsh.pant@xaviers.edu.in

\begin{abstract}
Plants have always been a vital source of medicines and other essential products that have been a part of human life ever since time immemorial. Pharmacognosy and its associated aspects have been going through constant evolution and investigation with every generation revealing different and new pharmaceutical properties of plants and their products. The horticulture sector of India has witnessed a great demand of exotic fruits and vegetables in the last decade. These are either imported or artificially introduced in an exotic and non-indigenous habitat. A large number of these exotic plants which are consumed as fruits and vegetables possess a variety of bioactive phytochemical compounds. These bioactive compounds impart them some really important medicinal and pharmacological properties such as anti-inflammatory, immunomodulatory, hepatoprotective, anticarcinogenic, antiulcerogenic, analgesics etc. This review article is an attempt to briefly address such exotic fruits and vegetables, the bioactive compounds associated with them and their medicinal properties useful to mankind.
\end{abstract}

KEY WORDS : Anti-inflammatory, Bioactive, Exotic, Phytochemical, Pharmacology

HOW TO CITE THIS ARTICLE : Pant, Harsh, Lobo, Vijaya, Santhosh, Anagha and Verma, Shashank (2020). Pharmacognosy and medicinal value of some exotic fruits and vegetables consumed in India. Asian J. Hort., 15(2) : 39-52, DOI : 10.15740/HAS/TAJH/15.2/39-52. Copyright@2020 : Hind Agri Horticultural Society
$\mathrm{P}$ lants have always been an integral part of pharmaceutical studies. Several plant based drugs and medicines are recommended for treatment of various diseases and disorders. According to an estimation by the World Health Organisation (WHO), 80 per cent of both rural and urban population across the globe makes huge health benefits from the usage of natural plant parts or plant based products (Chauhan and Singh, 2019). Natural plant products are usually reported to be safer than their synthetic counterparts. Even in the ancient times of Sushruta, plant based herbal remedies were practiced and it's the search of a better healthkind that humans over generations and through civilizations have tried to discover and use various plant products for their betterment (Ahmad and Ahamad, 2020). Plants are excellent sources of crude drugs which are claimed to have pharmaceutical properties (Porwal et al., 2020). Although the basis and roots of this field of ethnomedicine dates back to time immemorial, there is a considerable spurt in the research on herbal products and their potential applications in modern medicine (Leisegang, 2021). Not only plants famous for their medicinal properties are useful but there are several edible plant parts in our daily diet such as fruits and vegetables which carry a range of bioactive compounds that have medicinal properties.

The term exotic food products can be implied to those which are purchased or imported from other regions. The production area is usually not the same as that of the consumption region (Iyiade, 2013). In simple words, these are artificially introduced in a foreign habitat. 
The last decade has witnessed a spurt in the demand of exotic food products ranging from non traditional oils and various types of gourmet cheese to a variety of fruits and vegetables (Vinayak, 2020). The market production and associated economics for the same has grown by a leap of 15-20 per cent per annum and is still growing (Rao and Mrunalini Sasanka, 2015). As compared to farming of traditional vegetables and fruits, cultivation of exotic counterparts is economically a better option from the business point of view (Rao and Mrunalini Sasanka, 2015). Most of these fruits and vegetables are especially used in the recipes of salads and continental cuisine along with other exotic products.

Some of the most commonly consumed exotic fruits in India are Pomelo (Citrus maxima (Burm.) Merr.), Passion fruit (Passiflora edulis Sims.), Fingered citron (Citrus medica var. sarcodactylis swingle), Dragon fruit (Hylocereus undatus (Haw.) Britton and rose), Wood apple (Limonia acidissima Groff). Among the vegetables are broccoli (Brassica oleracea var. italica), bell peppers (Capsicum annum), sweet basil (Ocimum basilicum L.), lemon grass [Cymbopogon citratus (DC.) Stapf], chinese cabbage [Brassica rapa var. chinensis (L.) Kitam], parsley (Petroselinum crispum), thyme (Thymus vulgaris L.), Oyster mushroom (Pleurotus spp.), red or purple cabbage (Brassica oleracea var. Capitata f. rubra) etc.

With recent developments in nutrition sciences, people across India have been switching to usage of these fruits and vegetables for medicinal purposes and health benefits. The consumption has risen in popularity as a result of the correlation between fruits and the treatment of some severe diseases (Garcia and Chane, 2017). Certain fruits like Avocado, Mangosteen and Acai are reported to have well established anti inflammatory and antioxidant properties (Joshi et al., 2018).

Numerous exotic fruits are attracting a large population of India these days due to their high nutritious value and potential to treat a wide range of health issues (Madhuri, 2006). Like dragon fruit which is abundant in vitamin $\mathrm{C}$, lycopene, calcium, iron, potassium and other nutrients, is associated with improvement of kidney function, lower cholesterol, regulate sugar levels and avoid colon cancer (Suryono, 2006). Pomelo peel extract significantly reduces blood glucose levels by 70.17 per cent. The extract increased HDL cholesterol by 4.43 per cent while reducing total cholesterol levels by 30.86 per cent (Ani and Ochu, 2020). As per a research conducted by Xirui et al., 2020, Cycloartane triterpenoids obtained from passion fruit could be used to treat Alzheimer's disease and Parkinson's disease.

Several exotic vegetables show the presence of bioactive compounds which have pharmacognosy potential. Alkaloids obtained from vegetables such as chinese cabbage and broccoli can impart health benefits such as chemoprotective properties (Delgado et al., 2017). Extracts obtained from sweet basil are reported to contain hepatoprotective compounds, depressants of the central nervous system, immunity boosters and anticancer compounds (Ch et al., 2015). According to a study done by Okan et al. (2020) oils obtained from seeds of Parsley have a strong antioxidant and antifungal activities. Oyster mushrooms yield a type of $\beta$-glucan called pleuran which has some antiviral properties and can also be used to treat prostate and breast cancer (Golak et al., 2018). Decoction from lemon grass is reported to be antidiarrheal whereas its essential oils are effective in inhibiting the growth of Plasmodium berghei (Shah et al., 2011). Similarly there are many other health benefits as well as pharmaceutical properties of several other exotic fruits and vegetables as well.

This review article is an attempt to briefly describe some of the most commonly sold and consumed exotic fruits and vegetables in India with respect to their short taxonomic description, bioactive compounds, pharmacognosy potential and medicinal values.

\section{Asparagus spp.}

\section{Botanical description :}

Commonly referred to as sparrow grass, Asparagus is a perennial flowering plant which belongs to family Asparagaceae and was formerly a part of Liliaceae (Mfengwana and Mashele, 2021). The plant grows with a stout cylindrical stem possessing needle-like leaves and has bell shaped flowers (Gruben and Denton, 2004). The genus is reported to encompass around 300 species distributed primarily through Asian and European subcontinent (Joshi et al., 2010).

There are several notable species under this genus such as Asparagus officinalis L., Asparagus africanus Lam., Asparagus laricinus Burch., Asparagus racemosus Willd., etc. which are reported to have some pharmaceutical properties (Mfengwana and Mashele, 2021).

\section{Pharmacognosy and medicinal properties:}

Pise et al. (2015) indicated that the most important 
bioactive compounds reported in Asparagus racemosus Willd. are Shatavarins which are basically saponins with steroidal nature. They tried to assess the bioactivity of shatavarins using the lymphocytes from human blood and reported strong immunomodulatory effects which can be exploited for therapeutic purposes (Pise et al., 2015). Racemosol and racemofuran extracted from roots of Asparagus racemosus Willd. were found to be anticarcinogenic in nature (Agarwal et al., 2004). Extracts obtained from leaves and roots of Asparagus laricinus Burch. were shown to have anti-inflammatory effects owing to the presence of saponins (Just et al., 1998). Linoleic acid is the most commonly found bioactive compound in Asparagus officinalis L. (Jang et al., 2004). The effect of this compound present in the extracts of stems of Asparagus were reported to have inhibitory effects on cyclooxygenases and thus can impart anti-inflammatory properties.

The most important and commonly found bioactive compounds in the majority of the species of Asparagus are saponins which are indicated to be active in fighting against cancer. Saponins also have antimicrobial, antiinflammatory and antidiarrheal properties as well (Joshi et al., 2010). The Table 1. Given below summarises the various bioactive compounds and their pharmaceutical properties extracted from various parts of different species of Asparagus.

\section{Cymbopogon citratus Staph.}

\section{Botanical description:}

Cymbopogon citratus Staph. is an aromatic grass belonging to the family poaceae. It is commonly referred to as lemon grass is a tall sedge which is perennial. The leaves are ligulate, linear and tapering towards the upper parts and is widely cultivated artificially in the Indian subcontinent (Srivastava et al., 2013). The name Cymbogon is reflective of its flower spike arrangement which owes its roots to the Greek words kymbe and pogon which imply boat and beard. The plant is widely used in continental dishes for its sourness imparting flavour as well as aroma.

\section{Pharmacognosy and medicinal properties:}

Cymbopogon citratus is well documented for the aspects of pharmacognosy and is even traditionally used for its oils extracted from aerial parts which are used to treat indigestion and fever (Jeong et al., 2009). C. citratus is ranked as the top species from the genus Cymbopogon for its ethnomedicinal uses more prevelantely in the western Europe and parts of Eurasia.

Being an aromatic plant as well, $C$. citratus is mainly characterized for its essential oils. The most important phyto component in the essential oil obtained from lemongrass is Citral (Ming et al., 1996). Citral is a racemic mixture of geranial and neral in the trans and cis isomeric forms, respectively (Sarer et al., 1983). It has been reported that this component in the essential oil is really effective against amoebiasis as it inhibits the growth of Entamoeba histolytica. Citral, the essential oil, has also been shown to have antifungal properties and can inhibit certain human pathogenic fungi such as Candida albicans and Aspergillus niger and thereby can be used to treat fungal diseases such as candidiasis and aspergillosis (Boukhatem et al., 2014). Citral has also been shown to possess some anti inflammatory properties as studied by Boukhatem et al., 2014.

\section{Extracts from stalks of $\boldsymbol{C}$. citratus have been shown to cure diarrhea (Tangpu et al., 2006) :}

In a study on hepatocellular lesions induced by diethylnitrosamine (DEN) in rats it was found that the activity of DEN was inhibited by extracts from $C$. citratus thus citing its chemoprotective properties (Puatanachokchai et al., 2002).

Extracts from the leaves of lemongrass are also helpful in a dose dependent manner to reduce the cholesterol levels (Agbafor and Akubugwo, 2007). Extracts obtained using ethanolic concentrations are also reported to have anti mutagenic properties which was able to reduce or inhibit metastasis in the lungs of a rat model system of study (Puatanachokchai, 1994).

Essential oil from lemongrass is also a sedative and capable of inducing as well as extending sleep time as

\begin{tabular}{|lllll|}
\hline \multicolumn{2}{|l}{ Table 1 : Summarized research on pharmacognosy potential of bioactive compounds found in various parts of different Asparagus species } \\
\hline Name of the plant & Plant part used & Bioactive phtochemical & Medicinal properties & References \\
\hline Asparagus racemosus Willd. & Stem & Shatavarins & Immunomodulatory effects. & Pise et al., 2015 \\
Asparagus racemosus Willd. & Roots & Racemofuran and racemosol & Hepatoprotective properties & Agarwal et al., 2004 \\
Asparag us laricinus Burch. & Leaves and roots & Saponins & Anti-inflammatory & Just et al., 1998 \\
Asparagus officinalis L. & Stems & Linoleic acid & Anti-inflammatory & Jang et al., 2004 \\
\hline
\end{tabular}


reported by a study conducted on neural behaviour in mice using Cymbopogon citratus (Blanco et al., 2007).

\section{Ocimum basilicum L.}

\section{Botanical description :}

Ocimum basilicum L. is commonly referred to as sweet basil and belongs to the family Lamiaceae. It's a widely used exotic vegetable in preparation of continental dishes such as pesto sauce. Among the various other species under the genus Ocimum, sweet basil is one of the most widely cultivated condiments native to central and south african as well american regions (Barbalho et al., 2012). In India Ocimum sanctum or holy basil is more common. Ocimum basilicium is a medicinal as well as an aromatic plant with herbaceous habitat and a height of approximately 0.9 meters. The leaves are simple and opposite with a glabrous texture and a small petiole (Jayaweera, 1981). The leaves have certain oil glands which give off volatile essential oils. Flowers are usually small, bracteate and hermaphrodite (Kirtikar and Basu, 2003).

\section{Pharmacognosy and medicinal properties :}

Sweet basil is prominently known for its essential oils which confer it both medicinal and aromatic properties. Phytocharacterization of the essential oils obtained from the leaves of sweet basil reported two major compounds namely, chavicol (approximately 68\%) and linalool (approximately 26\%) (Padalia and Verma, 2011). Certain other products such as tannins, saponins, cardiac glycosides and flavonoids were also reported in the extracts from $O$. basilicum.

Methanolic extracts of the essential oils from basil can inhibit certain human pathogenic bacteria such as Vibrio cholerae. The analgesic properties of this extract was another finding reported in Swiss Mice which was nearly the same as the potential of the medicine, aspirin
(Choudhary et al., 2010). Further, this methanolic extract inhibits important proinflammatory cytokines and the associated receptors and therefore, possess antiinflammatory properties as well (Chinnasamy et al., 2006). Venâncio et al. (2011), suggested that the essential oil from sweet basil can potentially inhibit mediators such as prostaglandins which are associated with pain and hence, reflects certain antinociceptive effects. Ocimum basilicum L. is also shown to have inhibitory effects on $\alpha$-amylase and $\alpha$-glucosidase (El-Beshbishy and Bahashwan, 2012).

Certain other compounds isolated from Ocimum basilicum L. such as ursolic, 3-epi-maslinic, alphitolic, oleanolic, euscaphic and betulinic acids are beneficial to liver and are reported to be hepatoprotective in nature (Marzouk, 2009). Powders obtained from aerial parts of sweet basil were reported to show a decrease in the aspirin induced ulceration in mice and thus, is a reflection of its anti-ulcerogenic activity (Akhtar and Munir, 1989).

On the frog heart, an alcoholic extract of basil aerial parts had significant negative chronotropic and positive inotropic effects. The cardiotonic effect is caused by a significant decrease in membrane $\mathrm{Mg}+2 \mathrm{ATPase}$ and an increase in $\mathrm{Ca}+2$ and $\mathrm{Na}+/ \mathrm{K}+$ ATPase. The aqueous extract had ionotropic and chronotropic effects that were both positive. The aqueous and alcoholic extracts, respectively, developed cardiotonic and Badrenergic symptoms (Murlidharan and Dhananjayan, 2004). Sweet basil is thus, potentially a huge pharmaceutical plant with a varied range of medicinal properties. The Table 2 given below summarizes some of these medicinal properties of various parts of Ocimum basilicium L.

\section{Petroselinum crispum:}

Botanical description :

Petroselinum crispum (Mill.) Fuss, an Apiaceae member and known as Parsley, originated at Western

\begin{tabular}{|l} 
Table 2: Summarized pharmaceutical properties and bioactive compounds of O. basilicum L. \\
\begin{tabular}{|llll|}
\hline Type of extract and plant part used & Bioactive compounds identified & Medicinal properties & References \\
Methanolic extracts from leaves & Chavicol & Antimicrobial and antioxidant & Mohamad et al., 2011 \\
Ethanolic ex tracts from stem & Tannins & Anticarcinogenic and & Okwu and Emenike, 2006; \\
& & antiulcerogenic & Ruch et al., 1989 \\
Powder from aerial parts. & Saponins and Eugenol & Cardioprotective properties & Akhtar and Munir, 1989 \\
Extracts from leaves & Ursolic acid 3-epi-maslinic acid, & Hepatoprotective properties & Marzouk, 2009 \\
& alphitolic acid,oleanolic acid. & & Karimian et al., 2011 \\
Methanolic extracts from leaves & Linalool & Antioxidant & \\
\hline
\end{tabular}
\end{tabular}


Mediterranean region. P. crispum is an aromatic, erect annual herb with umbel inflorescence, pinnately compound leaves, bisexual flowers and bears shizocarp. Even though many cultivated varieties are reported for the plant, $P$. crispum var. neapolitanum, $P$. crispum var. crispum, $P$. crispum var. tuberosum are the three main varieties of $P$. crispum (Agyare et al., 2017).

\section{Pharmacognosy and medicinal properties:}

Okan et al. (2020) studied the chemical composition of the essential oil obtained from parsley seeds. Essential oil was extracted from the leaves and roots as well (Bruneton, 1999). It was reported that the oil consisted of $\beta$-pinene, $\alpha$-pinene, apiole, myrtenal, safrole, myristicin, 2.3.4.5-tetramethoxy-1-allylbenzene (Stankoviæ et al., 2005) and terpinolene (Orav et al., 2003). Enhanced antioxidant and antifungal activity was shown by the oil of parsley seeds due to the presence of these compounds. Most importantly, nephrotoxic and hepatotoxic activity was reported in apiole (Okan et al., 2020). Other major bio active compounds identified from $P$. crispum are the flavonoids (Pápay et al., 2012), which includes apigenin, luteolin, isorhamnetin, quercetin and chrysoeriol (Agyare et al., 2017). Apigenin and kaempferol were also detected from the leaf extracts by Gadi et al. (2012). Hudson (1949) reported the presence of a sugar in the leaf, stem and seeds of P. crispum, known as Apiose.

Several other pharmacological properties have been known to be exhibited by $P$. crispum like antiulcer, analgesic, anticoagulant, antidiabetic and spasmolytic (Agyare et al., 2017). The $P$. crispum roots serve as an excellent diuretic (Pharmacopoeia jugoslavica, 1951), for treating several illnesses such as cystitis, myalgia, functional amenorrhea, dyspepsia, menstrual disorders (Witchl and Bisset, 1994). The seeds of P. crispum are employed for treating kidney stones (Agyare et al., 2017) and gastritis (rehecho et al., 2011). It's also used as a carminative and diuretic as well (Rehecho et al., 2011). The $P$. crispum leaves are known for healing a variety of health issues like Skin diseases (Aljanaby, 2013), prostatitis, hyperuricaemia, anaemia, amenorrhoea, dysmenorrhea, induction of abortion (Benítez et al., 2010), and fluid retention management (Savikin et al., 2013).

\section{Pleurotus spp.}

Botanical description :

The Oyster mushroom belongs to the genus Pleurotus and comes under Basidiomycetes. They possess shell-like cap with lateral or eccentric stipe. They are observed growing on dead organic matter as they are capable of degrading lignocellulose (MartínezCarrera, 1998). Some of the major economically important Pleurotus species that is cultivated in India includes $P$. florida, P. pulmonarius, $P$. citrinopileatus (Khatun et al., 2015), P. ostreatus (17) and P. cystidiosus (Khan et al., 2008).

\section{Pharmacognosy and medicinal properties:}

The cell wall of the mushroom consists of the polysaccharides that exhibited high medicinal values, including $\alpha$-glucans and $\beta$-glucans (17). The carboxymethylation of $\alpha-(1 \rightarrow 3)$-glucans from $P$. citrinopileatus results in the formation of derivatives that possess high cytotoxic activity to cervical cancer cells, whereas it caused no harm to normal cells (Wiater et al., 2015). The development of neoplastic cells of Ehrlich tumor and sarcoma 180 was suppressed by the polysaccharides obtained from $P$. ostreatus (Facchini et al., 2014). Antinociceptive activity was shown by the $\beta$ glucans obtained from P. pulmonaris (Baggio et al., 2012). The proteins obtained from Pleurotus spp. also showed important economic properties. The apoptosis of neoplastic cells L929 and HeLa was induced by a haemolytic protein called Nebrodeolysin obtained from P. nebrodensis (Lv et al., 2009). The protein obtained from $P$. ostreatus possessed apoptotic activity towards monocytic leukaemia THP-1 and colorectal cancer cell line SW 480 (Wu et al., 2011) and those from $P$. cornucopiae exhibit antihypertensive properties (Jang et al., 2011).

The recent research on economic properties of Pleurotus spp. reveals the presence of several other bioactive compounds. An enzyme called Laccase was isolated from $P$. ostreatus that exhibited anti-viral effect towards hepatitis-C virus (El-Fakharana et al., 2010). The lectins extracted from $P$. citrinopileatus possessed antiviral and antineoplastic properties (Li et al., 2008). Wang et al. (2013) reported that the mycelium of $P$. cornucopiae contains terpenoids that are cytotoxic to HepG2 and HeLa cancer cells. Antihypercholesterolemic activity was exhibited by the lovastatin extracted from P. florida (Khan et al., 2011). The ergosterols obtained from $p$. cystidiosus possess antifungal properties (Menikpurage et al., 2009). The high composition of antiatherosclerotic agents like lovastatin, chrysin and ergothioneine in $P$. ostreatus makes it more significant 
in treating atherosclerosis (Abidin et al., 2017).

\section{Hylocereus undatus:}

Botanical description :

Hylocereus undatus (Haw.) Britton and rose which originated from Central and Northern South America and commonly known by different names like Dragon fruit, Night blooming Cereus, Strawberry Pear or Pithaya, belongs to the family Cactaceae (Kumar et al., 2018 and Perween et al., 2018). H. undatus is characterized by long, green stem, long flowers and the fruits that are usually rosy-red in colour, which is covered by long and large scales. The large white creamy flowers which bloom at night adds to their ornamental value. The growers from all around the globe are attracted to this fruit crop because of the delicious pulp of the fruit, its edible black seeds and appealing fruit colour (Perween et al., 2018).

\section{Pharmacognosy and medicinal properties:}

According to the studies conducted by Cheok et al. (2020), one of the major bioactive compounds found in Dragon fruits are the betalains. Around 85 per cent of their total phenolics are composed of betalainic compounds (Esquivel et al., 2007). High antioxidant activity is observed in these fruits due to the presence of natural antioxidants like betacyanin, phenolic acid, flavonoid, ascorbic acid, as well as fibres (Kumar et al., 2018; Choo and Yong, 2011; Komindr, 2004 and Wu et al., 2006).

Perween et al. (2018) studied the role of Dragon fruit in treating several health issues. High flavonoid content in these fruits is used to treat heart related diseases. It also acts against the bleeding issues associated with vaginal discharge. Experiments by
Poolsup and Suksomboon (2017) explained the role of Dragon fruit in treating prediabetes and type 2 diabetes. By regenerating $\beta$-cells of the pancreas and lowering the resistance of fibroblast growth factor-21 (FGF-21), Dragon fruit is reported to help in treating diabetes (Ismaviani, 2014 and Song et al., 2016). The insulin resistance is improved through purified peel betacyanins and white dragon fruit juice (Song et al., 2015 and 2016). Other health benefits include balancing of the production of blood by enhancing the levels of erythrocyte and haemoglobin, the formation of cardiac tissues, prevention of cancer in the colon and prostate and minimizing aortic stiffness (Kumar et al., 2018). These betalain rich fruits are also reported to enhance the functions of the endothelium and vascular system (Cheok et al., 2020).

\section{Citrus medica var. sarcodactylis swingle : \\ Botanical description :}

The rutaceae member Citrus medica L. var. sarcodactylis (Noot.) Swingle cultivated widely in China, Japan and Taiwan, is called by different names such as Fingered Citron, Longevity Orange and Buddha-Hand Citron (Li et al., 2019 and Peng et al., 2009). This small erect tree consists of ovate-lanceolate leaves, axillary spines, large flower buds, axillary flowers and holds berry with an aromatic and fragrant peel. The fruit possess finger- like sections that can be seedy or without seeds (Lim, 2012).

\section{Pharmacognosy and medicinal properties:}

The fingered citron was reported to be a rich source of flavonoids and the major flavonoids observed includes hesperidin, diosmetin-6-8-di- $C$-glucoside, diosmetin-6- $C$ glucoside, scutellarein 42-methyl ether 7-glucoside, limocitrol 3-alpha-1-arabinopyranosyl-(1->3)-galactoside.

\begin{tabular}{|c|c|c|c|c|}
\hline Sr. No. & Plant part used & Medicinal properties & Bioactive compounds & References \\
\hline 1. & $\begin{array}{l}\text { Stem and root } \\
\text { bark }\end{array}$ & Anti-inflammatory & $\begin{array}{l}\text { Xanthyletin, nordentatin, } \\
\text { atalantoflavon }\end{array}$ & (Chan et al., 2010) \\
\hline 2. & Stem bark & Anti-inflammatory, anticancer & Lonchocarpol & (Chanet al., 2009) \\
\hline 3. & Fruit & Hypoglycemic activity & $\begin{array}{l}\text { Essential oils (d-limonene, } \gamma \text { - } \\
\text { terpenene, } \beta \text {-pinene, } \alpha \text {-pinene) }\end{array}$ & (Peng et al., 2009) \\
\hline 4. & Fruit peel & $\begin{array}{l}\text { influences the activities of autonomous nervous } \\
\text { system and emotions }\end{array}$ & Essential oils & $\begin{array}{l}\text { (Sayorwan and Rumruay, } \\
\text { 2017) }\end{array}$ \\
\hline 5. & Fruit peel & $\begin{array}{l}\text { Enhance the respiratory rate, blood pressure and } \\
\text { decreased drows iness }\end{array}$ & Essential oils & $\begin{array}{c}\text { (Hongratanaworakit and } \\
\text { Buchbauer, 2007) }\end{array}$ \\
\hline
\end{tabular}


These compounds are shown to improve anti-aging and antioxidant activity (Luo et al., 2020). Researches indicate that the citron peel is composed of limonene, and also consists of several other compounds such as steroids, p-coumaric acids, nomilin, triterpenoids (Feng and Fengchang, 2004 and Yin et al., 2004) and gamma terpinene (Shiota, 1990). In Table 2, the pharmaceutical properties of bioactive compounds associated with different parts of plants are summarised (Lim, 2012).

Studies done by Jiang et al. (2001) indicated that the xiayou decoction (made of 15 herbal components and one among them is fingered citron) was used to treat mental health problems like anxiety and depression in the functional dyspepsia (FD) patients. The fruit is also used to treat distension and pain in the chest (Lim, 2012).

\section{Citrus maxima :}

Botanical description:

Citrus maxima (Burm.) Merr., also called as Pomelo or Shaddock, is a citrus plant that belongs to the family Rutaceae and are grown in warm climates of Southeast Asia, including India, Indonesia, Taiwan, China and the Philippines (Thielen et al., 2013). C. maxima is a perennial tree with an average length of 5-10 m and are hermaphrodite. Pink and white fleshed fruits are observed with a size of about $30 \mathrm{~cm}$ width, that is yellowish green in colour and looks like pear. The petiolate leaves possess a citrus odour and the flowers have a sweet fragrance (Abirami et al., 2013).

\section{Pharmacognosy and medicinal properties:}

Pomelo extract has been related to a range of health effects, including anti-toxic, heart stimulant, anti-diabetic, and also promotes hypercholesterolemia (Ani and Anigam, 2018). Some bioactive compounds, like flavonoids and saponins are present in C. maxima peel that decreases the chances of acquiring chronic diseases such as diabetes (Elekofehinti, 2015). In herbal medicine, C. maxima is being used to cure a number of health problems like diabetes, heart diseases, etc (Ajeet and Navneet, 2017). Treatment of cough, fever, cancer and stomach conditions all involve the use of fruit (Kalidhar and Kaur, 2013).

EtOH is an alcoholic substance obtained from pericarp, mesocarp and leaves of $C$. maxima; serves as a growth inhibitor for various bacteria such as $E$. coli., Salmonella typhimurium and $P$. aeruginosa (Borah et al., 2012 and Das et al., 2013). And EtOH isolated from leaf and bark has anti-neoplastic activity of upto 69.1 per cent and 15 per cent, respectively (Shivanand et al., 2013). According to Shivanand et al. (2013) research, EtOH derived from stem bark functions as a hypoglycemic agent in diabetes (induced by streptozotocin).

The highest activity against $S$. typhimurium and $K$. pneumoniae is found in a $\mathrm{MeOH}$ extracted from pulp and leaves of C. maxima, So it is a quality curative agent for Typhoid and Pneumonia (Abirami et al., 2013). A research done by Obah et al., 2014 proves that juice extracted from $C$. maxima acts as an inhibitor against Angiotensin Converting Enzyme (ACE). DL-limonene (essential oil) obtained from C. maxima, prevents liver damage by blocking the formation of aflatoxin in the human body (Singh et al., 2016).

\section{Passsiflora edulis:}

Botanical description :

Passion fruit or Passiflora edulis, found in the tropics and subtropics mainly in South America, Caribbean, south Florida, South Africa and Asian countries (Xirui et al., 2016). Passiflora genus belongs to the family Passifloraceae with approximately 500 sps. For commercial and medical purposes, Passiflora edulis is the most popular (Dhawan et al.,2004). The plant list contains other varieties such as $P$. edulis Sims, $P$. edulis $f$. edulis and $P$. edulis f. flavicarpa. P. edulis var. kerii (Spreng.) etc. With purple fruits and black seeds, $P$. edulis is the most popular and widespread perennial climber. The peel is bright yellow, dense and hard. The

\begin{tabular}{|c|c|c|c|c|}
\hline Sr. No. & Plant part used & Medicinal properties & B ioactive compounds & References \\
\hline \multirow[t]{2}{*}{1.} & Pericarp and & Treatment of typhoid, urinary tract infections & $\mathrm{EtOH}$ & (Borah et al., 2012 and \\
\hline & mesocarp & & & Das et al., 2013) \\
\hline 2. & Leaf and stem bark & Anticancer and hypoglycemic activity & $\mathrm{EtOH}$ & (Shivanand et al., 2013) \\
\hline 4. & Fruit pulp and leaves & curative agent for typhoid and pneumonia & $\mathrm{MeOH}$ & (Abirami et al., 2013) \\
\hline 5. & Fruit peel & prevents liver damage & Essential oil (DL-Limonen) & (Singh et al., 2016) \\
\hline
\end{tabular}


pulp has a pleasant aroma and a $\mathrm{pH}$ of 6 or lower (Narain et al., 2010). Striate stem upto $16 \mathrm{~cm}$ long and more than $9 \mathrm{~cm}$ long tendrils are present at the axis. The leaves are 3 lobed at each node and borne along the stem alternately in an ascending spiral. $2.5 \mathrm{~cm}$ long filamentous corona, white petals and 2 glands at the petiole's apex are discerning features of the flower (Souza et al., 2004).

\section{Pharmacognosy and medicinal properties:}

The majority of pharmacological studies on P. edulis have focused on its central nervous system (CNS) functions. $P$. edulis extracts have been shown to have possible therapeutic benefit. It is used as a tranquiliser and also very beneficial for the treatment of ADHD (attention-deficit hyperactivity disorder), anxiety, cancer, insomnia, etc. (Spencer and Seigler, 1983). Many phytochemicals such as flavonoids, alkaloids, phenols, cyanogenic compounds, terpenoids and others can be extracted from different parts of $P$. edulis (Taiwe and Kuete, 2017) P. edulis derivatives were shown to have hypoglycemic and antioxidant properties when used to treat streptozotocin-induced diabetes (Kandandapani et al., 2015) .

Enzyme gelatinase matrix metalloproteinases (MMP-2 and MMP-9) which causes metastatic tumor in humans can be inactivated by water extract of $P$. edulis (Puricelli et al., 2003). 5,7-dihydroxyflavone acts as a great ligand for CNS as well as PBRs (peripheral benzodiazepine receptors) and in this way it acts as a great remedy for depression/anxiety (Medina et al., 1990). P. edulis plant extract contains luteolin-6-Cglucoside. It also contains gamma amino butyric acid (GABA) that aids in the treatment of myocardial infarction (Ichimura et al., 2006). Pe-AFP-1 (peptide) is isolated from the brown seed for P. edulis and acts as a potential compound for the treatment of Peritonitis, Endopathalmitis and Chronic Pulmonary Infection. because it inhibits the growth of Trichoderma harzianum, Fusarium oxysporum and Aspergillus fumigatus, respectively (Pelegrini et al., 2006).

\section{Limonia acidissima Groff :}

Botanical description:

Limonia acidissima Groff is a tropical fruit that grows in Southern Asian countries like Sri Lanka, Bangladesh, India and it belongs to the family Rutaceae. For maximum fruit and inflorescence development, it prefers a semi-arid or dry environment. The plant's sustainable age is estimated to be between 12-70 years (Sharma et al., 2014). Commonly called as a wood apple. If we're talking about India, this species can be found in Maharashtra, Chhattisgarh, Uttar Pradesh, Madhya Pradesh and the western portion of Himalyan Range (Kumar, 2017). It's a sluggish tree with some upwardgrowing branches that curve laterally and are partitioned into narrow branchlets that droop at the tops, it shed seasonally. The fruit's surface layer is extremely tough and brownish, while the flesh is bitter and has seeds trapped inside it. leaves are lumpy, alternative, greenish, and alternate. Flowers are tiny, abundant, reddish or green and are loosely trapped in panicles at the marginal ends of branches. The flesh is thick red, smelly, resinous, astringent, sour and sweet and contains white seeds (Vijayvargia and Vijayvergia, 2014).

\section{Pharmacognosy and medicinal properties:}

Flavonoids, saponins and tannins are found in $L$. acidissima. Few coumarins and tyramine products have also been reported in its fruit (Ilango and Chitra, 2009). Several organic chemicals present in this fruit, such as carotenoids, flavonoids, tyramines which are helpful in reducing the risk of many lethal disorders like cancer, Hypertension, etc (Abdollahi et al., 2004). Coumarins have anticoagulant, COX-inhibitory and vasodilator properties. Dihydromyrcenol, a recent coumarin, is obtained from a methanol extract of Limonia acidissima's root-bark (Ghosh et al., 1982). Two

\begin{tabular}{|c|c|c|c|c|}
\hline Sr. No. & Plant part used & Medicinal properties & Bioactive compounds & References \\
\hline 1. & Fruit (water ex tract) & Anti-depressant & Flavonoid (5,7dihydroxyflav one) & (Medina et al., 1990) \\
\hline 2. & leaf & aids in the treatment of myocardial & GABA (Gamma Amino Butyric & (Ichimura et al., 2006) \\
\hline & & infarction & Acid) & \\
\hline 3 . & Seed & $\begin{array}{c}\text { for the treatment of peritonitis, } \\
\text { end opathalmitis }\end{array}$ & Peptide (Pe-AFP-1) & (Pelegrini et al., 2006). \\
\hline
\end{tabular}


limonoids, obacunone and acidissima were extracted from the stem bark and root bark of Limonia acidissima which aid in the treatment of cancers of colon, mouth, breast and lungs (John et al., 2004).

Tyramine is an amino acid that aids in blood pressure regulation and recently two new tyramine derivatives, acidissiminol and acidissiminin epoxidized were isolated from the fruit of Wood Apple (Gosh et al., 2004). leaf juice extract with honey or milk act as a potential remedy for intestinal problems Enterobiasis, Ascariasis, etc. The fruit of the Limonia acidissima has antineoplastic activity (Mishra et al., 2009).

\section{Conclusion:}

Exotic fruits and vegetables have shown a tremendous and sudden increase in their appearance in the horticulture sector. These products have a much greater potential associated with pharmacognosy aspects than merely being high priced condiments. Vegetables like Cymbopogon citratus Staph., Ocimum basilicum L. are highly investigated medicinal and aromatic plants which have been known to the humankind as ethnomedicinal plants. With recent development in pharmacognosy, these plants have intrigued researchers for their essential oils which provide a range of medicinal properties such as anti-inflammatory, anticarcinogenic, sedative, analgesic etc. With a growing demand for mushrooms in the food sector, genera such as Pleurotus, Agaricus provide a sound basis for their medicinal aspects besides being a delicacy. Other fruits such as Passiflora edulis Sims, Citrus maxima (Burm) Merr., Hylocereus undatus (Haw.) Britton and Rose etc. are not just medically sound with potent antioxidant properties but also provide health benefits such as immunity which is a key factor to avoid various diseases. Thus, these exotic foods can be a promising asset to the field of health sciences in developing preventive medicines for various diseases. In depth investigation of these plants for their toxicology and biological activities with bioactives isolation and characterisation would bring some new insights. Also the metabolism of these bioactive compounds in target organisms needs to be studied as well. These exotic fruits and vegetables provide the local growers an access to commercial markets, as the customers are attracted by their nutraceutical importance and exotic properties, thereby increasing the revenue of the agricultural sector. With a great future prospective, these exotic food products show case a potent pharmacognital value which need to be further investigated and valued in the Indian horticulture and study of medicinal properties of plants.

\section{REFERENCES}

Abdollahi, M., Ranjbar,A., Shadnia, S., Nikfar, S. and Rezaiee, A. (2004). Pesticides and oxidative stress: A Review. Med. Science Monit., 10 : 141-147.

Abidin, M.H.Z., Abdullah, N. and Abidin, N. Z. (2017). Therapeutic properties of Pleurotus species (Oyster mushrooms) for atherosclerosis: A review. Internat. J. Food Propert., 20 (6) : 1251-1261.

Abirami, A., Nagarani, G. and Siddhuraju, P. (2013). Antibacterial activity of crude extract of Citrushystrix and Citrus maxima. Int. J. Pharma.Sci. Res., 4 (1) : 296-300.

Agbafor, K.N. and Akubugwo,E.I.(2007). Hypocholesterolaemic effect of ethanolic extract of fresh leaves of Cymbopogon citratus (lemon grass) African J. Biotechnol., 6 : 596-598.

Agrawal, A., Sharma, M., Rai, S.K., Singh, B., Tiwari, M. and Chandra, R. (2008). The effect of the aqueous extract of the roots of Asparagus racemosus on hepatocarcinogenesis initiated by diethylnitrosamine. Phytotherapy Research.,2 (22) :1175-1182

Agyare, C., Appiah, T., Boakye, Y.D. and Apenteng, J.A. (2017). Petroselinumcrispum: a review. Medicinal Spices and Vegetables from Africa, Academic Press, 527-547pp.

Ahmad, J. and Ahamad, J. (2020). Drug discovery from plant sources: Scope, approach and challenges. Bioactive Phytochemicals: Drug discovery to product development, 113.doi: $10.2174 / 9789811464485120010004$

Akhtar, M.S. and Munir, M. (1989). Evaluation of the gastric antiulcerogenic effects of Solanumnigrum, Brassica oleracea and Ocimumbasilicum in rats. J. Ethnopharmacology, 27(12): 163-76.

Ali, A.H. and Kitabul, Mukhtarat (2007). Fit tib (Urdu Translation).Vol II. New Delhi: CCRUM, 75-76 pp.

Aljanaby, A.A.J.J. (2013). Antibacterial activity of an aqueous extract of Petroselinumcrispum leaves against pathogenic bacteria isolated from patients with burns infections in Alnajaf Governorate, Iraq. Res. Chem. Intermed., 39 (8) : 37093714.

Ani, P. N. and Aginam, P. C. (2018). Effect of Citrus maxima juice on fasting blood glucose, lipid profile, liver enzyme and body weight. Nutr. Food Sci., 48 : 755-763.

Ani, P. and Ochu, K. (2020). Anti-diabetic, anti-hyperlipidemic and hepatoprotective potential of shaddock (Citrus maxima) peel extract. Acta Sci. Pol. Technol. Aliment., 19 (3) : 271-278. 
Baggio, C.H., Freitas, C.S., Marcon, R., Werner, M.F.P., Rae, G.A., Smiderle F.R., Sassaki, G. L., Iacomini, M., Marques, M.C.A. and Santos, A.R.S. (2012). Antinociception of $\beta$-Dglucan from Pleurotus pulmonarius is possibly related to protein kinase C inhibition. Int. J. Biol. Macromol., 50 : 872877 .

Bandaranayake, W.M. (2006). Quality control, screening, toxicity and regulation of herbal drugs, In: Modern phytomedicine. Turning Medicinal Plants into Drugs eds Ahmad I., Aqil F., Owais M. (Weinheim:Wiley-VCHGmbH and Co. KGaA; ) 25-57 10.1002/9783527609987.ch2.

Barbalho, S., Machado, F., Rodrigues, J., Silva, T. and Goulart, R. (2012). Sweet basil (Ocimum basilicum): much more than a condiment. Tang. Humanitas Medicine, 2(1) : 3.1-3.5. doi: 10.5667/tang.2011.0023.

Baroh, M., Ahmed, S. and Das, S. (2012). A comparative study of the antibacterial activity of the ethanolic extracts of Vitexnegunda L., Fragariavesca L., Terminaliaarjuna and Citrus maxima. Asi. J. Pharma. Biol. Res., 2(3): 183-187.

Benítez, G., González-Tejero, M.R. and Molero-Mesa, J. (2010). Pharmaceutical ethnobotany in the western part of Granada province (southern Spain): ethnopharmacological synthesis. J. Ethnopharmacol., 129 (1) : 87-105.

Blanco, M.M., Costa, C.A., Freire, A.O., Santos, J.G. and Costa, I.M. (2007). Neurobehavioral effect of essential oil of Cymbopogoncitratus in mice. Phytomedicine, 16 : 265-270.

Bruneton, J. (1999). Pharmacognosy, phytochemistry medicinal plants, $2^{\text {nd }}$ Ed., Intercept Ltd, London, pp. 519-520.

Chandrasekhara Rao, C.C. and Mrunalini, Sasanka V. (2015). Exotic veggies: A practical utility of innovation lured by the easy returns. Internat. J. Appl. Res.,1(12): 1038-1041.

Chan, Y.Y., Li, C.H., Shen, Y.C. and Wu, T.S. (2010). Antiinflammatory principles from the stem and root barks of Citrus medica.Chem Pharm Bull. (Tokyo) 58 (1) : 61-65.

Chan, Y.Y., Wu, T.S. and Kuo, Y.H. (2009). Chemical constituents and cytotoxicity from the stem bark of Citrus medica. Heterocycles, 78 (5) : 1309-1316.

Cheok, A., George, T. W., Rodriguez-Mateos, A. and Caton, P. W. (2020). The effects of betalain-rich cacti (dragon fruit and cactus pear) on endothelial and vascular function: a systematic review of animal and human studies. Food \& Function, 11(8): $6807-6817$.

Chinnasamy, S., Balakrishnan, G., Kontham, S.V., Baddireddi, S.L. and Balakrishnan, A. (2007). Potential anti-inflmmatory properties of crude alcoholic extract of Ocimum basilicum L. in human peripheral blood mononuclear cells. J. Health Science, 53 (4) : 500-505.

Ch, M., Naz, S., Sharif, A., Akram, M. and Saeed, M. (2015).
Biological and pharmacological properties of the sweet basil (Ocimum basilicum). British J. Pharmaceutical Research, 7(5): 330-339. doi: 10.9734/bjpr/2015/16505.

Choo, W. S. and Yong, W. K. (2011). Antioxidant properties of two species of Hylocereus fruits. Advances in Applied Science Research, 2 (3) : 418-425.

Choudhury, G.B., Prabhat, K.J., Nayak, B.S., Panda, S.K. and Tripathy, S.K. (2010). Phytochemical investigation and evaluation of analgesic activity of leafy extracts of various Ocimum (Tulsi) species. The Indian Pharmacist, 8 (12): 67-70.

Das, S., Baroh, M. and Ahmed, S. (2013). Antibacterial activity of the ethanolic extract of leaves of citrus maxima (Burm.) Merr. On Escherichiacoli and Pseudomonas aeruginosa. Asi. J. Pharma. Clin. Res., 6 (4) : 136-139.

De, Blasi V., Debrot, S., Menoud, P.A., Gendre, L. and Schowing, J.J.(1990). Amoebicidal effect of essential oils in vitro Toxicol. Clin. Exp.,10 (6) : 361-373.

Delgado, Martins A, Parisi, S, Daniel, M. and Vaz, Almeida (2017). Greens and other vegetable foods chemistry of the mediterranean diet. Springer Int Publishing, pp. 59-137.

Dhawan, K., Dhawan, S. and Sharma, A. (2004). Passiflora: a review update. J.Ethnopharmacol., 94 : 1-23. doi: 10.1016/ j.jep.2004.02.023.

El-Beshbishy, H.A. and Bahashwan, S.A. (2012). Hypoglycemic effect of basil (Ocimum basilicum) aqueous extract is mediated through inhibition of \{alpha\}-glucosidase and \{alpha\}-amylase activities: An in vitro study. Toxicol. Ind. Health, $28: 42-50$.

Elekofehinti, O.O. (2015). Saponins: Anti-diabetic principles from medicinal plants - A review. Pathophysiol., 22 : 95-103.

El-Fakharany, E.M., Haroun, B.M., Ng, T.B. and Redwan E.R., (2010). Oyster mushroom laccase inhibits hepatitis $\mathrm{C}$ virus entry into peripheral blood cells and hepatoma cells. Protein Pept. Lett., 17 : 1031-1039.

Esquivel, P., Stintzing, F. C. and Carle, R. (2007). Phenolic compound profiles and their corresponding antioxidant capacity of purple pitaya (Hylocereus sp.) genotypes. ZeitschriftfürNaturforschung C, 62 (9-10) : 636-644.

Facchini, J.M., Alves, E.P., Aguilera, C., Gern, R.M.M., Silveira, M.L.L.,Wisbeck, E. and Furlan, S.A. (2014). Antitumor activity of Pleurotusostreatus polysaccharide fractions on Ehrlich tumor and Sarcoma 180. Int. J. Biol. Macromol., 68 : 72-77.

Feng, Y. and Fengchang, L. (2004). Studies on the constituents of Citrus medica L. var. Sarcodactylis. Zhongguoyaoxuezazhi (Zhongguoyaoxuehui: 1989), 39 (1) : 20-21.

Gadi, D., Bnouham, M., Aziz, M., Ziyyat, A., Legssyer, A., Bruel, 
A., Berrabah, M., Legrand, C., Fauvel Lafeve, F. and Mekhfi, H., (2012). Flavonoids purified from parsley inhibit human blood platelet aggregation and adhesion to collagen under flow. J. Complement. Integr.Med., 9 : 19.

Golak-Siwulska, I., Kaluzewicz, A.,Spizewski, T., Siwulski, M., and Sobieralski, K. (2018). Bioactive compounds and medicinal properties of Oyster mushrooms (Pleurotus sp.). Folia Horticulturae, 30 (2) : 191-201. doi: 10.2478/fhort2018-0012.

Gosh, P., Sil, P. and Das, S. (2004). Tyramine derivatives from the fruit of Limoniaacidissima. J. Natural Products, 54 (5): DOI: 10.1021/np50077a24.

Gracia, R. and Chanes, J. (2017). Exotic fruit juices. Innovation Tech. in Beverage Processing, 5 (10) : 1102.

Grubben, G.J.H. and Denton, O.A. (2004). Plant resources of tropical Africa, 2 : Vegetables. PROTA Foundation, Wageningen; Backhuys, Leiden; CTA, Wageningen.

He, X., Luan, F., Yang, Y., Wang, Z., Zhao, Z., Fang, J., Wang, M., Zuo, M. and Li, Y. (2020). Passifloraedulis:An insight into current researches on phytochemistry and pharmacology. Front. Pharmacol., dol: 10.3389/fphar.2020.00617.

Hildah, Mfengwana, P. and Sitheni Mashele, S. (2021). Medicinal properties of selected Asparagus species: A Review. Matrix Sci. Pharma., 4 : 18-21.

Hongratanaworakit, T. and Buchbauer, G. (2007). Autonomic and emotional responses after transdermal absorption of sweet orange oil in humans: placebo controlled trial. Internat. J. Essential Oil Therapeutics, 1 : 29-34.

https://www.indiaperspectives.gov.in/en_US/indias-exoticfood-basket. 27 February, 2021.

Hudson, C.S. (1949). Apiose and the glycosides of the parsley plant. Adv. Carbohydr. Chem., 4 : 57-74.

Ichimura, T., Yamanaka, A., Ichiba, T., Toyokawa, T., Kamada, Y., Tamamura, T. and Maruyama, S. (2006). Antihypertensive effect of an extract of Passifloraedulis rind in spontaneously hypertensive rats. Biosci.Biotechnol.Biochem., 70 (3): 718-721.

Ismaviani, N.D. (2014). Effect of red dragon (Hylocereus polyrhizus) fruit pulp juice on blood glucose and regeneration of beta-pancreatic cells in alloxan-induced diabetic rats [abstract of BSc thesis]. Faculty of Pharmacy.Widya Mandala Catholic University Surabya.

Iyiade, A.F. (2013). Comparative economic analysis of indigenous and exotic vegetables in Ibadan metropolis, Oyo State, Nigeria. Pacific J. Sci. Technol., 14 : 246-250.

Jang, D.S., Cuendet, M., Fong, H.H.S., Pezzuto, J.M. and Kinghorn, A.D. (2004). Constituents of Asparagus officinalis evaluated for inhibitory activity against cyclooxygenase-2. $J$.
Agric. \& Food Chem., 52 (8) : 2218-2222.

Jang, J.H., Jeong, S.C., Kim, J.H., Lee, Y.H., Ju, Y. C. and Lee, J.S. (2011). Characterization of a new antihypertensive angiotensin 1-converting enzyme inhibitory peptide from Pleurotuscornucopiae. Food Chem., 127 : 412-418.

Jayaweera, D.M.A. (1981). Medicinal plants, (Indigenous and Exotic) used in ceylon. Part III. Colombo: The National Science Foundation of Sri Lanka pp.101-3.

Jeong, M.R., Park, P.B., Kim, D.H., Jang, Y.S., Jeong, H.S. and Choi, S.H. (2009). Essential oil prepared from Cymbopogon citrates exerted an antimicrobial activity against plant pathogenic and medical micro-organisms. Mycobiology, $37: 48-52$.

Jiang, B., Lin, J. and Zhang, Y. (2001). Clinical observation on Xiaoyu decoction plus psychotherapy in treating functional dyspepsia. Chin. J. Integr. Med., 7 (1) : 19-21.

Joshi, G., Rawat, M., Bisht, V., Negi, J. and Singh, P. (2010). Chemical constituents of Asparagus. Pharmacognosy Reviews, 4 (8) : 215. doi: 10.4103/0973-7847.70921.

Joshi, S., Jadhav, V. and Kadam, V. (2018). Exotic fruits and vegetable food as nutritional supplement for diadetes, obesity and metabolic diseases. Internat. J. Curr. Pharmaceut. Res., 10 (2) : 51. doi: 10.22159/ijcpr.2018v10i2.25843.

Just, M.J, Recio, M.C., Giner, R.M., Cullar, M.J., Manez, S. and Bilia, A.R. (1998). Antiinflammatory activity of unusual Lupanesaponins from Bupleurum fruticescens. Planta Medica., 64 : 404-407.

Kandandapani, S., Balaraman, A.K. and Ahamed, H.N. (2015). Extracts of passion fruit peel and seed of Passifloraedulis (Passifloraceae) attenuate oxidative stress in diabetic rats. Chin. J. Nat. Med., 13 (9) : 680-686.

Karimian, P., Kavoosi, G. and Saharkhiz, M.J. (2011). Antioxidant, nitric oxide scavenging and malondialdehyde scavenging activities of essential oils from different chemotypes of Zatariamultiflora. Nat. Prod. Res., 26(22) : 2144-2147. doi: 10.1080/14786419.2011.631136.

Khan, M.A., Amin, S. R., Uddin, M. N., Tania, M. and Alam, N. (2008). Comparative study of the nutritional composition of oyster mushrooms cultivated in Bangladesh. Bangladesh $J$. Mushroom, 2 (1) : 9-14.

Khan, M.A., Rahman, M.M., Tania, M., Uddin, M.N. and Ahmed, S. (2011). Pleurotussajor-caju and Pleurotusflorida mushrooms improve some extent of the antioxidant systems in the liver of hypercholesterolemic rats. Open Nutraceuticals J., $4: 20-24$.

Khatun, S., Islam, A., Cakilcioglu, U., Guler, P. and Chatterjee, N.C. (2015). Nutritional qualities and antioxidant activity of 
Harsh Pant, Vijaya Lobo, Anagha Santhosh and Shashank Verma

three edible oyster mushrooms (Pleurotus spp.). NJASWageningen J. Life Sci., 72 : 1-5.

Kirtikar, K.R. and Basu, B.D. (2003). Indian medicinal plants with illustrations. $2^{\text {nd }}$ Ed.VIII. Uttaranchal: Oriental Enterprises, 2701-2705 pp.

Kirtikar, R.R. and Basu, B.D. (2008). Indian medicinal plants, 1. International Book Distributors, 495-496pp.

Komindr, S. (2004). Phytate and fibre content in Thai fruits commonly consumed by diabetic patients. J. Med. Assoc. Thai., 87 (12): 1444-1446.

Kumar, A. and Deen, B. (2017). Studies on preparation and storage of jelly from wood apple (Limoniaacidissima) fruits. $J$. Pharmacognosy \& Phytochemistry, 6 (6) : 224-229.

Kumar, S.B., Issac, R. and Prabha, M. L. (2018). Functional and health-promoting bioactivities of dragon fruit. Drug Invention Today, 10 (3) : 3307-3310.

Leisegang, K. (2021). Herbal pharmacognosy: An introduction. Herbal Medicine In Andrology, 17-26. doi: 10.1016/b978-0-12815565-3.00003-5.

Li, Y.R., Liu, Q.H., Wang, H.X. and Ng, T.B. (2008). Anovel lectin with potent antitumor, mitogenic and HIV1 reverse transcriptase inhibitor activities from the edible mushroom Pleurotuscitrinopileatus. Biochim.Biophys.Acta Gen. Sub., 1780 : $51-57$.

Li, Z.H., Cai, M., Yang, K. and Sun, P. L. (2019). Kinetic study of d-limonene release from finger citron essential oil loaded nanoemulsions during simulated digestion in vitro. J. Functional Foods, 58 : 67-73.

Lim, T. K. (2012). Citrus medica var. sarcodactylis. In : Edible medicinal and non-medicinal plants, Springer, Dordrecht, pp. $690-694$.

Llango, K. and Chitra, V. (2010). Wound healing and antioxidant activities of the fruit pulp of Limoniaacidissima Linn. (Rutaceae) in Rats .Trop. J. Pharm. Res., 37: 120-125.

Luo, X., Wang, J., Chen, H., Zhou,A., Song, M., Zhong, Q. and Cao, Y. (2020). Identification of flavoanoids from finger citron and evaluation on their antioxidative and antiaging activities. Frontiers in Nutrition, 7: 584900. PMID 33195374 DOI: 10.3389/ fnut.2020.584900.

Lv, H., Kong, Y., Yao, Q., Zhang, B., Leng, F.W., Bian, H.J., Balzarini, J., Damme, E.V. and Bao, J. K. (2009). Nebrodeolysin, a novel hemolytic protein from mushroom Pleurotus nebrodensis with apoptosis-inducing and anti-HIV1 effects. Phytomed., $16: 198-205$.

MacLeod, J., Moeller, P. and Bandara, R. (2004). Acidissimin, a new limonoid from Limoniaacidissima. J. Nat. Prod., 52 (4): DOI: $10.1021 / \mathrm{np50064a040.}$
Madhuri, S. (2017). Nutritive and medicinal value of dragon fruit, Asian J. Hort., 12 : 267-271.

Martínez-Carrera, D. (1998). Cultivation of oyster mushrooms. USDA database, 242-245pp.

Marzouk, A.M. (2009). Hepatoprotective triterpenes from hairy root cultures of Ocimum basilicum L. Z Naturforsch C., 64 : 201-209.

Medina, J.H., Paladini,A.C., Wolfman, C., de Stein, M.L., Calvo, D., Diaz, L.E. and Peña, C. (1990). Chrysin (5,7-di-OH-flavone), a naturally-occurring ligand for benzodiazepine receptors, with anticonvulsant properties. Biochem.Pharmacol., 40 (10) : 2227-2231.

Menikpurage, I.P., Abeytunga, D.T.U., Jacobsen, N.E. and Wijesundara, R.L.C. (2009). An oxidize ergosterol from Pleurotus cystidiosus active against anthracnose causing Colletotrichum gloeosporioides. Mycopathologia, 167 : 155 162.

Ming, L., Figueiredo, R., Machado, S. and Andrade, R.(1996). In: Proceedings of the International Symposium on Medicinal and Aromatic Plants. Mexico: Acta Horticulturae Leiden; 1996. Yield of essential oil of and citral content in diff erent parts of lemongrass leaves (Cymbopogoncitratus (DC.) Stapf.) Poaceae; pp. 555-559.

Mishra, A., Arora, S., Gupta, R., Manvi-Punia, R.K. and Sharma, A.K. (2009). Effect of Feroniaelephantum (Correa) fruit pulp extract on indomethacin-induced gastric ulcer in albino rats. Tropical J. Pharmaceutical Research,8 : 509-514.

Mohamad, R.H., El-Bastawesy,A.M.,Abdel-Monem, M.G., Noor, A.M.,Al-Mehdar, H.A., Sharawy, S.M. and El-Merzabani, M.M. (2011). Antioxidant and anticarcinogenic effects of methanolic extract and volatile oil of fennel seeds (Foeniculum vulgare). J. Med. Food, 14 : 986-1001.

Mohamed, Nadjib, Boukhatem, Mohamed, Amine, Ferhat, Abdelkrim, Kameli, Fairouz, Saidi and Hadjer, Tchoketch Kebir (2014). Lemon grass (Cymbopogon citratus) essential oil as a potent anti-inflammatory and antifungal drugs, Libyan J. Medicine, 9 : 1, DOI: 10.3402/ljm.v9.25431.

Morton, J.F. (1987). Mexican lime. In: Fruits of warm climates, 1sted; Creative Resource System: Winterville, 1987, NC, USA, $168-172$.

Muralidharan, A. and Dhananjayan, R. (2004). Cardiac stimulant activity of Ocimum basilicum Linn extracts. Indian J. Pharmacol., 36 : 163-166.

Narain, N., Nigam, N. and de, Sousa Galvão, M. (2010). Passion fruit, In : Handbook of fruit and vegetable flavours, Wiley Online Library. Chapter 20, 345-389. doi: 10.1002/978047062 2834.ch20.

Oboh, G., Fatai, O. Bello and Ayokunle, O. (2014). Ademosun, 
Hypocholesterolemic properties of grapefruit (Citrus paradisii) and Shaddock (Citrus maxima) juices and inhibition of angiotensin-1-converting enzyme activity. J. Food \& Drug Analysis, 22 : 477-484.

Okan, O., Kilic, A., Onaran, A., Oz, M. and Denyz, Y. (2020). Endüstriyel ölçekteüretilen Nar (Punica granatum L.) ve Maydanoz (Petroselinum crispum) to humuyaðýnýnkimyas albilepimi, antioksidanve antifungal özelliklerininbelirlenmesi. Artvin Çoruh Üniversitesi Orman Fakültesi Dergisi. doi: 10.17474/artvinofd.683260.

Okan, O. T., Pekozlu, A. K., Onaran, A., Mehmet, O. Z. and Deniz, Y. (2020). Determination of chemical composition, antioxidant and antifungal properties of pomegranate (Punica granatum L.) and parsley (Petroselinum crispum) seed oil produced in industrial scale. Artvin Çoruh Üniversitesi Orman Fakültesi Dergisi, 21(2) : 1-11.

Okwu, D.E. and Emenike, I.N. (2006). Evaluation of the phytonutrients and vitamin contents of citrus fruits. Int. J. Mol. Med. Adv. Sci., 2 : 1-6.

Orav, A., Kailas, T. and Jegorova, A. (2003). Composition of the essential oil of dill, celery and parsley from Estonia. In: Proceedings-estonian Acad. Sci. Chem., 52 (4): 147-154).

Padalia, R.C. and Verma, R.S. (2011). Comparative volatile oil composition of four Ocimum species from northern India. Nat. Prod. Res., 25 : 569-575.

Pápay, Z.E., Kósa, A., Boldizsár, I., Ruszkai, A., Balogh, E. and Klebovich, I. (2012). Pharmaceutical and formulation aspects of P. crispum extract. Acta Pharm. Hung., 82 (1) : 3-14.

Pelegrini, P.B., Noronha, E.F., Muniz, M.A.R., Vasconcelos, I.M., Chiarello, M.D., Oliveira, J.T.A. and Franco, O.L. (2006). An antifungal peptide from passion fruit (Passifloraedulis) seeds with similarities to $2 \mathrm{~S}$ albumin proteins. Biochim. Biophys. Acta, 1764 (6) : 1141-1146.

Peng, C. H., Ker, Y. B., Weng, C. F., Peng, C. C., Huang, C. N., Lin, L. Y. and Peng, R. Y. (2009). Insulin secretagogue bioactivity of finger citron fruit [Citrus medica (L.) var. Sarcodactylis Hort, Rutaceae]. J. Agric. \& Food Chemistry, 57 (19) : 8812-8819.

Perween, T., Mandal, K. K. and Hasan, M. A. (2018). Dragon fruit: An exotic super future fruit of India. J. Pharmacognosy \& Phytochemistry, 7(2): 1022-1026.

Pharmacopoeia Jugoslavica, I.I. (1951). Farmakopeja FNRJ, Pharmacopoeajugoslavica, editiosecunda, Medicinskaknjiga, Beograd.

Pise, M.V., Rudra, J.A. and Upadhyay, A. (2015). Immunomodulatory potential of shatavarins produced from Asparagus racemosus tissue cultures. J. Nat. Sci. Biol. Med., 6 : 415 - 420 .
Poolsup, N., Suksomboon, N. and Paw, N. J. (2017). Effect of dragon fruit on glycemic control in prediabetes and type 2 diabetes: A systematic review and meta-analysis. Plos. One, 12 (9): e0184577.

Porwal, O., Singh, S.K., Patel, D.K., Gupta S, Tripathi, R. and Katekhaye, S. (2020). Cultivation, Collection and Processing of Medicinal Plants.Bioactive Phytochemicals: Drug Discovery To Product Developmen, 14-30.doi: 10.2174/9789811 464485120010004.

Puatanachokchai, R.(1994). Antimutagenicity, cytotoxicity and antitumor activity from lemon grass (Cymbopogon citratus, Stapf) extract, Master's thesis, Faculty of Medicine. Thailand: Chiang Mai University; 1994.

Puricelli, L., Dell'Aica, I., Sartor, L., Garbisa, S., and Caniato, R. (2003). Preliminary evaluation of inhibition of matrixmetalloprotease MMP-2 and MMP-9 by Passifloraedulis and $P$ foetida aqueous extracts. Fitoterapia, 74 : 302-304. doi: 10.10 16/S0367-326X(03)00023-6

Rehecho, S., Uriate-Pueyo, I., Calvo, J. and Calvo, M.I. (2011). Ethnopharmacological survey of medicinal plants in NorYauyos, a part of the Landscape Reserve Nor-Yauyos-Cochas. Peru. J. Ethnopharmacol., 133 (1) : 75-85.

Ruch, R.J., Cheng, S.J. and Klaunig, J.E. (1989). Prevention of cytotoxicity and inhibition of Intercellular communication by antioxidant catechins isolated from Chinese green tea. Carcinogenesis., 10 : 1003-1008.

Sarer, E., Scheffer, J.J. and Baerheim, S.A. (1983). Composition of the essential oil of Cymbopogoncitratus (DC.) Stapf cultivated in Turkey. ScientiaPharmaceutica,51 : 5863.

Savikin, K., Zdunic, G., Menkovic, N., Zivkovic, J., Cujic, N., Terescenko, M. and Bigovic, D. (2013). Ethnobotanical study on traditional use of medicinal plants in South-Western Serbia, Zlatibor district. J. Ethnopharmacol., 146 (3) : 803-810.

Sayorwan, W. and Rumruay, V. (2017).Chemical compositions of fingered citron peel [Citrus medica (L.) var. Sarcodactylis] and its effect on the autonomic nervous system. J. Health Research, 31 (4) : 307-313.

Sharma, H. P., Patel, H., Sharma, S. and Vaishali (2014). Study of physico-chemical changes during wood apple, Feronialimonia maturation. J. Food Res. \& Technol.,2 (4): 148-152.

Shiota, H. (1990). Volatile components in the peel oil from fingered citron [Citrus medica (L.) var. sarcodactylis Swingle]. Flavour \& Fragrance J., 5 (1) : 33-37.

Shivananda, A., Muralidhara, R.D. and Jayaveera, K.N. (2013). Analgesic and anti-inflammatory activities of Citrus maxima (J. Burm) Merr. in animal models. Res. J. Pharma, Biol. Chem. 
Harsh Pant, Vijaya Lobo, Anagha Santhosh and Shashank Verma

Sci., 4 (2): 1800.

Singh, A., Pathak, V.M. and Navneet (2016). Screening of Antimicrobial potential of Barleriaprionitis Linn aerial parts against common respiratory tract pathogens. Int. J. Curr. Microbio. Appl. Sci., 5 (7) : 542-549.

Singh, A. and Navneet (2017). Citrus maxima (Burm.) Merr. A traditional medicine: Its antimicrobial potential and pharmacological update for commercial exploitation in herbal drugs - A Review, Internat. J. Chem.Tech. Res., 10 (5):642-651.

Song, H., Chu, Q., Xu, D., Xu, Y. and Zheng, X. (2016). Purified betacyanins from Hylocereusundatus peel ameliorate obesity and insulin resistance in high-fat-diet-fed mice. J. Agric. \& Food Chemistry, 64 (1) : 236-244.

Song, H., Zheng, Z., Wu, J., Lai, J., Chu, Q. and Zheng, X. (2016). White pitaya (Hylocereusundatus) juice attenuates insulin resistance and hepatic steatosis in diet-induced obese mice. PLoS One, 11(2) : e 0149670.

Souza, M.M., Pereira, T.N.S., Viana, A.P., Pereira, M.G., do, Amaral Júnior, A.T. and Madureira, H.C. (2004). Flower receptivity and fruit characteristics associated to time of pollination in the yellow passion fruit Passifloraedulis Sims $\mathrm{f}$. flavicarpa Degener (Passifloraceae). Sci. Hortic., 101 (4) : 373385.

Spencer, K.C. and Seigler, D.S. (1983). Cyanogenesis of Passifloraedulis. J. Agric. Food Chem., 31 (4) : 794-796.

Srivastava, V., Dubey, S. and Mishra, A. (2013). A review on lemon grass: Agricultural and Medicinal aspect. Internat. Res. J. Pharm., 4 (8) : 42-44. doi: 10.7897/2230-8407.04807.

Stankoviæ, M. Z., Stanojeviæ, L. P., Nikoliæ, N. È. and Cakiæ, M.D. (2005). The effect of parsley [Petroselinumcrispum (Mill.) Nym.ex. AW Hill] seeds milling and fermentation conditions on essential oil yield and composition. Chemical Industry \& Chemical Engineering Quarterly/CICEQ, 11(4) : 177-182.

Suryono, J. (2006). Consuming dragon fruit to treat various diseases. Sinar. Tani., 15-21 pp.

Tangpu, V. and Yadav, T.A. (2006). Some important folklore medicinal plants used by Tangkhul Nagas of Ukhrul District, Manipur. TX, USA: Recent Progress in Medicinal Plants.

Tchoumbougnang, F., Zollo, P.H., Dagne, E. and Mekonnen, Y. (2005). In vivo antimalarial activity of essential oils from Cymbopogoncitratus and Ocimumgratissimum on mice infected with Plasmodium berghei. Planta Medica, 71: 20-23.

Venâncio, A.M., Onofre, A.S., Lira, A.F., Alves, P.B., Blank, A.F., Antoniolli, A.R., Marchioro, M., Estevam, C.S. and de, Araujo B.S. (2011). Chemical composition, acute toxicity and antinociceptive activity of the essential oil of a plant breeding cultivar of basil (Ocimum basilicum L.). Planta Med.,77: 825829.

Vijayvargia, P. and Rekha, V. (2014). A review on Limoniaacidissima L.: Multipotential medicinal plant. Int. J. Pharm. Sci. Rev. Res., 28 (36) : 191-195.

Wang, S., Bao, L., Zhao, F., Wang, Q., Li, S., Ren, J., Li, L., Wen, H., Guo, L. and Liu, H. (2013). Isolation, identification and bioactivity of monoterpenoids and sesquiterpenoids from the mycelia of edible mushroom Pleurotuscornucopiae. $J$. Agric. Food Chem., 61 : 5122-5129.

Wiater, A., Paduch, R., Pleszczyñska, M., Próchniak, K., Choma, A., Kandefer-Szerszen, M. and Szczodrak, J. (2011). $\alpha-(1 \rightarrow 3)$-D-Glucans from fruiting bodies of selected macromycetes fungi and the biological activity of their carboxymethylated products. Biotechnol. Lett., 33 : 787-795.

Wichtl, M. and Bisset, N.G. (1994). Herbal drugs and phytopharmaceuticals, Medpharm Scientific Publishers, Stuttgart.

Wu, J.Y., Chen, C.H., Chang, W.H., Chung, K.T., Liu, Y.W., Lu, F.J. and Chen, Ching-Hsein (2011). Anti-cancer effects of protein extracts from Calvatialilacina, Pleurotusostreatus and Volvariellavolvacea. Evid.-Based Complement.Alternat.Med., doi:10.1093/ecam/neq057.

Wu, L. C., Hsu, H. W., Chen, Y. C., Chiu, C. C., Lin, Y. I. and Ho, J.A.A. (2006). Antioxidant and antiproliferative activities of red pitaya. Food Chemistry, 95(2):319-327.

Xu, F.Q., Wang, C., Yang, L., Luo, H., Fan, W., Zi, C., Dong, F., Hu, J. and Zhou, J. (2013). C-dideoxyhexosyl flavones from the stems and leaves of Passifloraedulis Sims. Food Chem., 136 : 94-99. doi: 10.1016/j.foodchem.2012.07.101.

Yin, F., Cheng, L. and Lou, F.C. (2004). Studies on the constituents of Citrus medica L. var. sarcodactylis (Noot.) Swingle. Zhongguo. Tianran. Yaowu., 2 (3) : 149-151.

Zhang, Y. H. (2018). A kind of Passifloraedulis drink rich in organic chromium [Machine Translation]. Faming Zhuanli. Shenqing., CN 107821886 A20180323.

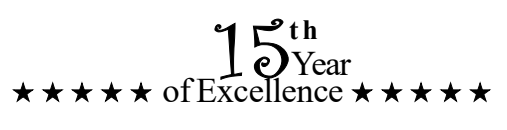

